\title{
Critical thermal limits of Poecilia caucana (Steindachner, 1880) (Cyprinodontiformes: Poeciliidae)
}

\author{
Juan Diego Martínez , Carlos Daniel Cadena ${ }^{1}$ and Mauricio Torres²
}

\begin{abstract}
Although temperature has far-reaching effects on fish biology, the thermal tolerance ranges of most freshwater fish species are unknown. This lack of information precludes forecasting responses to climatic change and does not allow for comparative analyses that may inform evolutionary and biogeographic studies. We used the critical thermal methodology to quantify acclimation capacity and thermal tolerance in the Neotropical freshwater species Poecilia caucana. For fish acclimated to $20^{\circ} \mathrm{C}, 25^{\circ} \mathrm{C}$, and $28^{\circ} \mathrm{C}$, critical thermal minima $\left(\mathrm{CT}_{\text {min }}\right)$ were $12.52 \pm 0.62^{\circ} \mathrm{C}, 13.41 \pm 0.56^{\circ} \mathrm{C}$ and $14.24 \pm 0.43^{\circ} \mathrm{C}$ respectively, and critical thermal maxima $\left(\mathrm{CT}_{\max }\right)$ were $38.43 \pm 0.64^{\circ} \mathrm{C}, 40.28 \pm 0.92^{\circ} \mathrm{C}$ and $41.57 \pm 0.27^{\circ} \mathrm{C}$, respectively. Both $\mathrm{CT}_{\text {min }}$ and $\mathrm{CT}_{\max }$ changed with acclimation temperatures, indicating that $P$. caucana was effectively acclimatable. Relative to values reported for other freshwater fish species, the acclimation capacity of $P$. caucana for $\mathrm{CT}_{\min }$ was low, but it was average for $\mathrm{CT}_{\max }$. The data, together with similar work in other species, can be used in analyses focusing on broad ecological and evolutionary questions.

Aunque la temperatura tiene grandes repercusiones en la biología de los peces, se desconocen los rangos de tolerancia térmica de la mayoría de los peces dulceacuícolas. Esta falta de información impide pronosticar respuestas al cambio climático y limita los análisis comparativos que podrían enriquecer estudios evolutivos y biogeográficos. Utilizamos la metodología del crítico térmico para cuantificar la capacidad de aclimatación y la tolerancia térmica en la especie neotropical dulceacuícola Poecilia caucana. Para peces aclimatados a $20^{\circ} \mathrm{C}, 25^{\circ} \mathrm{C}$ y $28^{\circ} \mathrm{C}$, los críticos térmicos mínimos $\left(\mathrm{CT}_{\min }\right)$ fueron $12,52 \pm 0,62^{\circ} \mathrm{C}, 13,41 \pm 0,56^{\circ} \mathrm{C}$ y $14,24 \pm 0,43^{\circ} \mathrm{C}$, respectivamente, y los críticos térmicos máximos $\left(\mathrm{CT}_{\max }\right)$ fueron 38,43 $\pm 0,64^{\circ} \mathrm{C}, 40,28 \pm 0,92^{\circ} \mathrm{C}$ y $41,57 \pm 0,27^{\circ} \mathrm{C}$, respectivamente. Tanto el $\mathrm{CT}_{\text {min }}$ como el $\mathrm{CT}_{\text {max }}$ cambiaron significativamente con las temperaturas de aclimatación, indicando que $P$. caucana es efectivamente aclimatable. Comparada con otras especies de peces dulceacuícolas, la capacidad de aclimatación de $P$. cuacana fue baja para $\mathrm{CT}_{\min }$ y promedio para $\mathrm{CT}_{\max }$. Estos resultados, en conjunto con los datos de otras especies, pueden ser utilizados para responder preguntas ecológicas y evolutivas más generales.
\end{abstract}

Keywords: Acclimation capacity, Colombia, Physiological ecology, Thermal tolerance range.

\section{Introduction}

Temperature influences crucial organismal traits such as energy use, growth, reproduction, and development (Johnston \& Bennett, 1996). Temperature is especially important for ectotherms, including fishes, because of its influence on metabolic rate and physiological efficiency (Hoffman et al., 2012; Ohlberger et al., 2012). Some fish traits influenced by temperature are foraging pattern and foraging ability (Persson, 1986), locomotor capacity (Bennett, 1990), sexual selection (Johansen, 1985), mating preferences (Johansen, 1985), and life-history traits such as age at sexual maturity (Kuparinen et al., 2011). Accordingly, temperature has been suggested to be the abiotic factor with strongest effect on fish biology (Brett, 1971).
When organisms are exposed to changes in temperature, they may display various strategies to stay within tolerance limits so that vital biological processes and physiological rates are maintained. These strategies vary from behavioral (moving to more comfortable sites), to physiological (e.g., phenotypic plasticity in enzyme conformation or plasmatic membrane fluidity; Di Prisco \& Giardina, 1996; Gracey et al., 1996), to evolutionary (e.g., evolution of dormancy stages; Marshall \& Sinclair, 2011). One of the first steps to study the effect of temperature on the biology of any species is to determine its range of thermal tolerance. However, this sort of information is still lacking for most freshwater fish species.

Collecting data on thermal tolerances of organisms is especially relevant given the urgency to determine the ability

\footnotetext{
${ }^{1}$ Laboratorio de Biología Evolutiva de Vertebrados, Departamento de Ciencias Biológicas, Universidad de los Andes, Carrera 1 \# 18A-12, Bogotá, Colombia. (JDM) jd.martinez340@uniandes.edu.co, (CDC) ccadena@uniandes.edu.co

${ }^{2}$ Fundación Iguaque, Estación Biológica Bomarea, Tona, Colombia. mauriciotorres@iguaque.org (corresponding author)
} 
of species to persist in the face of ongoing anthropogenic climate change (Sala et al., 2000; Stillman, 2003; Pörtner \& Farrell, 2008). The need for this kind of data is particularly pressing for tropical species because these may show overall higher susceptibility to climatic changes (Deutsch et al., 2008; Sheldon et al., 2011). However, data on temperature tolerance ranges are especially scarce for tropical freshwater species. In addition, the limited existing data are difficult to examine in a comparative framework because studies used dissimilar methodologies that measure different aspects of physiological limits and experimental parameters such as time, rate of temperature increase, and endpoint of the experiment are not consistent across studies. The lack of basic information and consistent methodology has thus prevented the analysis of thermal tolerance of fishes in broad ecological and evolutionary contexts (e.g. Ghalambor et al., 2006; Araújo et al., 2013).

We estimated the range of temperature tolerance for the Cauca Molly, Poecilia caucana (Steindachner, 1880), a Neotropical Poeciliid species from the Magdalena River basin of Colombia. We assessed thermal tolerance using the critical thermal methodology, a non-lethal procedure that requires relatively few individuals (Lutterschmidt \& Hutchinson, 1997; Beitinger et al., 2000). We measured critical thermal maximum $\left(\mathrm{CT}_{\max }\right)$ and critical thermal minimum $\left(\mathrm{CT}_{\text {min }}\right)$ on fish obtained in the field and acclimated to three different temperatures in the laboratory. Using these data, we estimated the capacity of this species to vary its $\mathrm{CT}_{\min }$ and $\mathrm{CT}_{\max }$ values when acclimated to different temperatures. Despite Colombia's rich freshwater fish fauna (Maldonado et al., 2008), this is the first study to report thermal tolerance ranges for any of its fish species. In addition, we estimated the thermal tolerance polygon for $P$. caucana and compared it to existing data on other tropical fish species. Although the available data are still too limited to reach any definitive conclusions about patterns of variation in thermal tolerance among tropical fishes, our work is one the first efforts to synthetize the existing information (Prodocimo \& Freire, 2001).

\section{Material and Methods}

Fish collection and acclimation period. Adult males and females of $P$. caucana were collected in September 2013 with a seine in a man-made pond in the municipality of Guapotá, Santander, Colombia $\left(6^{\circ} 20^{\prime} 30 \mathrm{~N} 73^{\circ} 18^{\prime} 25 \mathrm{~W}\right.$, $1350 \mathrm{~m}$ elevation). We assume that thermal tolerances of these fish should be similar to those from other natural populations of this species because the pond was connected to a natural stream, which connects the pond population to other natural populations, and because this species prefers low-flow habitats similar to the source pond (Maldonado-Ocampo et al., 2006). Surface temperature was measured in situ three times to calculate a mean value $\left(25.13 \pm 0.21^{\circ} \mathrm{C}\right)$. Fish were transported to the Universidad de los Andes in Bogotá less than 24 hours after capture to be kept at constant conditions $\left(25^{\circ} \mathrm{C}\right)$ for one week in three 42-1 fish-tanks in the laboratory. Fish were then transferred to different 42-1 fish-tanks (65 fish per tank) with constant aeration and experienced three different acclimation temperatures $\left(\mathrm{T}_{\mathrm{a}}\right): 25^{\circ} \mathrm{C}$ (the average field temperature), $20^{\circ} \mathrm{C}$ (the most common temperature in studies of critical thermal limits), and $28^{\circ} \mathrm{C}$ (the highest stable temperature with the equipment available to us). The different acclimation temperatures were chosen to assess the acclimation ability of the species and to determine whether critical thermal limits depend on the conditions to which fish were acclimated. Two replicate tanks were set at each temperature for a total of six tanks in which we allowed fish to acclimate for at least 30 days (Lutterschmidt \& Hutchinson, 1997). During this time, temperature was kept constant with Shark H-229 thermo regulators. Fish were fed ad libitum, taking care to remove excess food; $25 \%$ of the water was changed in each tank every two days with treated tap water and commercial API Stress Coat.

Estimation of critical thermal limits. $\mathrm{CT}_{\max }$ and $\mathrm{CT}_{\min }$ are physiological upper and lower limits that are determined by acclimating animals to different temperatures and then exposing them to a constant linear increase or decrease in temperature until a predefined sub lethal endpoint is reached. In fishes, the characteristic sub lethal endpoint is typically recognized by loss of equilibrium and a halt in opercular movements (Lutterschmidt \& Hutchinson, 1997). $\mathrm{CT}_{\max }$ was defined as the temperature at which acclimated fish subjected to increasing temperature showed loss of equilibrium (LOE; Beitinger et al., 2000; Currie et al., 1998). LOE is not lethal, as most fish survive the experiment ( $94 \%$ in this study). The water temperature was changed at a constant rate of $0.3^{\circ} \mathrm{C} / \mathrm{min}$, either heating it using four Shark H-229 thermo regulators, or cooling it with a MC-1/4HP AquaEuroUSA Cooling Chiller. The volume of water in the experimental tanks was 301 and 10 1 for the $\mathrm{CT}_{\text {min }}$ and $\mathrm{CT}_{\text {max }}$ tests, respectively. These volumes were established given our ability to modify temperatures based on our equipment. Styrofoam was used as insulation, covering the sides and bottom of the experimental tank. Experiments started at the same temperature at which fish were acclimated; after LOE was reached, fish were immediately transferred to water with the same temperature as that in their respective acclimation tanks. A total of 399 fish were tested, 183 in $\mathrm{CT}_{\max }$ trials and 216 in $\mathrm{CT}_{\min }$ trials. For each trial the number of fish tested ranged between 8 and 24.

Once we determined $\mathrm{CT}_{\max }$ and $\mathrm{CT}_{\min }$, we estimated a thermal tolerance polygon, the thermal area in which the species may survive (Lutterschmidt \& Hutchinson, 1997; Beitinger et al., 2000). We measured acclimation capacity as the change in critical thermal limit divided by the change in acclimation temperature $\left(\Delta \mathrm{CT} / \Delta \mathrm{T}_{\mathrm{a}}\right)$; this quantity indicates the degree to which organisms are able to adjust their thermal sensitivity given changes in environmental 
temperature (Stillman, 2003). Because no statistical difference was found between replicate tanks (t-test, $p>0.05$ ), all the data for each acclimation temperature were pooled when testing for acclimation capacity. We tested the effect of acclimation and fish tanks on $\mathrm{CT}_{\text {min }}$ and $\mathrm{CT}_{\max }$ using one-way within-subjects ANOVA and Tukey's multiple comparisons tests implemented in $\mathrm{R}$ 3.0.1. ( $\mathrm{R}$ Development Core Team, 2015).

Finally, based on a literature review, we compared the estimates of thermal tolerance for $P$. caucana with data for 13 species in six orders of fishes. These species had reports of mean (and standard deviation, SD) $\mathrm{CT}_{\text {min }}$ and $\mathrm{CT}_{\max }$ for at least two acclimation temperatures. We conducted randomizations to test whether the acclimation capacities for both $\mathrm{CT}_{\min }$ and $\mathrm{CT}_{\max }$ differed between $P$. caucana and other freshwater species. We performed four separate randomizations of the slopes of the lines describing acclimation capacity, i.e. the line connecting $\mathrm{CT}_{\min }$ or $\mathrm{CT}_{\max }$ (Y-values) at different $\mathrm{T}_{\mathrm{a}}$ (X-values), two for $\mathrm{CT}_{\min }$ and two for $\mathrm{CT}_{\max }$. With the first randomization for each CT we tested whether the slopes estimated for $P$. caucana were higher than those estimated for other species, and with the second we tested whether the slopes of $P$. caucana were lower than those of other species. In each of these randomizations, $p$-values were calculated as the number of times that simulated slopes were either lower or higher in P. caucana than in each of the other species, divided by the total number of runs (10,000 times). We adjusted significance values due to multiple comparisons by performing a false discovery rate test (Verhoeven et al., 2005), which determines an alpha value that decreases from 0.05 in proportion to the number of statistical tests performed, in this case 13 (one for each comparison between $P$. caucana and the 13 species having CT mean and SD data).

\section{Results}

For fish acclimated to $20^{\circ} \mathrm{C}, 25^{\circ} \mathrm{C}$, and $28^{\circ} \mathrm{C}, \mathrm{CT}_{\text {min }}$ were $12.52 \pm 0.62^{\circ} \mathrm{C}, 13.41 \pm 0.56^{\circ} \mathrm{C}$ and $14.24 \pm 0.43^{\circ} \mathrm{C}$ respectively, and $\mathrm{CT}_{\max }$ were $38.43 \pm 0.64^{\circ} \mathrm{C}, 40.28 \pm 0.92^{\circ} \mathrm{C}$ and $41.57 \pm 0.27^{\circ} \mathrm{C}$, respectively (Fig. 1, 2). We found that Poecilia caucana is acclimatable with respect to thermal tolerance: both $\mathrm{CT}_{\min }$ and $\mathrm{CT}_{\max }$ increased significantly with acclimation temperature (one-way ANOVAs, $\mathrm{p}<0.001$; Fig. 1). The area comprised by the thermal tolerance polygon was $214.65^{\circ} \mathrm{C}^{2}$. The acclimation capacity of the $\mathrm{CT}_{\min }$ of $P$. caucana was 0.17 , on the lower end of that observed in all 13 other species it was compared to, and significantly lower than that of Micropterus salmoides $(\mathrm{p}<0.001)$, Ictalurus punctatus $(\mathrm{p}<0.001)$, Pangasius pangasius $(\mathrm{p}<0.001)$, Carasius auratus $(\mathrm{p}=0.025)$, and Danio rerio $(\mathrm{p}=0.020$; Fig. 3). The acclimation capacity of the $\mathrm{CT}_{\text {max }}$ of $P$. caucana was 0.31 . This value was similar to that observed in all 13 other species it was compared to and not significantly lower than that reported for any other freshwater species (Fig. 3), but was statistically higher than that of four other species (Oncorhynchus mykiss, $\mathrm{p}=0.018 ;$ Labeo rohita, $\mathrm{p}=0.015$; Cirrhinus mrigala, $\mathrm{p}<0.001$; and P. pangasius, $\mathrm{p}=0.007$ ).

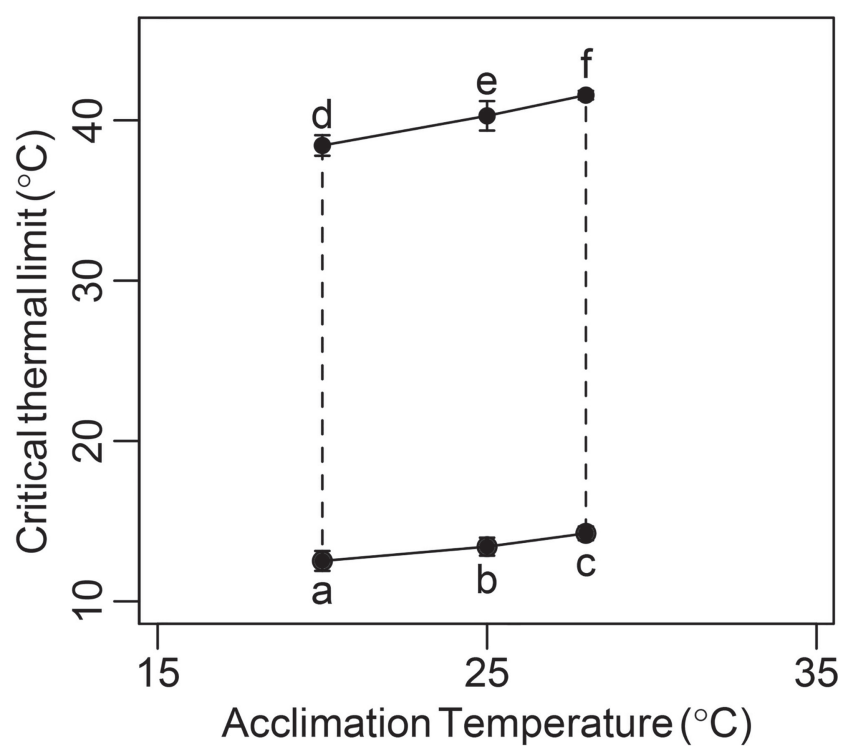

Fig. 1. Thermal tolerance limits of Poecilia caucana. Values represent mean $\pm \mathrm{SD}$ in critical thermal limits estimated for each acclimation temperature. Letters represent significant differences in the Tukey post-hoc test using $\alpha=0.05$.

\section{Discussion}

Poecilia caucana showed a high upper thermal tolerance $\left(\mathrm{CT}_{\max }\right)$ relative to other freshwater fishes, i.e. it has a $\mathrm{CT}_{\max }$ higher than $40^{\circ} \mathrm{C}$ (Fig. 2). High upper thermal tolerance is characteristic of other members of the family Poeciliidae and in general of members of the order Cyprinodontiformes (Fig. 2; Beitinguer et al., 2000: table 8). The highest documented $\mathrm{CT}_{\text {max }}$ of any Poeciliid is $42.3 \pm 0.4^{\circ} \mathrm{C}$, observed in Gambusia affinis acclimated at $35^{\circ} \mathrm{C}$ (Otto, 1973). Our data suggest that $P$. caucana may tolerate higher temperatures if acclimated at higher temperatures than those used in this study, because after acclimation at $25^{\circ}$ it showed a higher $\mathrm{CT}_{\max }$ than G. affinis $\left(40.28 \pm 0.92^{\circ} \mathrm{C}\right.$ vs. $38.0 \pm 0.4^{\circ} \mathrm{C}$; Otto, 1973$)$. Moreover, the $\mathrm{CT}_{\max }$ value for $P$. caucana is only slightly lower than that reported for some species of Cyprinodontiformes with the highest heat-tolerance (e.g., Cyprinodon sp., $\mathrm{CT}_{\max }=41.7 \pm 0.19^{\circ} \mathrm{C}$ at $\mathrm{T}_{\mathrm{a}}=25^{\circ} \mathrm{C}$; Otto \& Gerking, 1973). Therefore, $P$. caucana may be among the species with the highest $\mathrm{CT}_{\max }$ in the order, but this needs further tests with individuals acclimated to higher temperatures than those available to us, and more studies should be conducted on other species in the order (e.g., species inhabiting thermal springs likely have greater $\mathrm{CT}_{\max }$ values than those reported so far for this group).

In contrast to its high tolerance for high temperatures, $P$. caucana was relatively intolerant to cool temperatures, i.e., $\mathrm{CT}_{\min }$ in all treatments was higher than $10^{\circ} \mathrm{C}$ (Figs. 1-2). Other poeciliids tolerate lower temperatures. For 
example, the $\mathrm{CT}_{\text {min }}$ of Poeciliopsis occidentalis, Poecilia sphenops, and Poecilia latipinna were $4.8^{\circ} \mathrm{C}, 7.5^{\circ} \mathrm{C}$, and $7.6^{\circ} \mathrm{C}$, respectively (Bulger \& Schultz, 1982; Hernández et al., 2002; Bierbach et al., 2010). Because all these species occur at higher (i.e. cooler) latitudes than $P$. caucana, the data appear consistent with the hypothesis that thermal tolerance ranges are narrower in organisms from lower latitudes (Janzen, 1967; Sheldon \& Tewksbury, 2014). In a forthcoming study, we test this hypothesis in a phylogenetic framework.

Relative to other freshwater fish species, the acclimation capacity of $P$. caucana was low for $\mathrm{CT}_{\min }(0.17)$ and close to average for $\mathrm{CT}_{\max }(0.31$; Fig. 3). Compared to other poeciliids, $P$. caucana has a lower heat acclimation capacity than G. affinis, although estimates for the latter species vary considerably between two studies (i.e., 0.34 vs. 0.43; Otto, 1973, 1974). This variation may be explained by environmental differences between populations or by differences in the range of acclimation temperatures (the first study used a wide range from $5{ }^{\circ} \mathrm{C}$ to $35{ }^{\circ} \mathrm{C}$ and the second a range from $25{ }^{\circ} \mathrm{C}$ to $35^{\circ} \mathrm{C}$ ). Thus, comparative studies should bear in mind that data collected from thermal tolerance experiments depend strongly on experimental conditions (Terblanche et al., 2007).
To our knowledge there are no functional studies of $P$. caucana that may allow one to explain the limited tolerance to cold temperatures of the species. A possible mechanism involved is oxygen limitation, proposed as the strongest physiological barrier establishing thermal limits (Pörtner \& Knust, 2007). There are, however, multiple other mechanisms that may be involved, including reductions in heart function, mitochondrial respiration, membrane static order (fluidity), action potential generation, protein synthesis, heat-shock protein expression, and protein thermal stability (Somero, 2002).

A limitation to any ecophysiological study arises from the geographical origin of the studied species. As with most studies reporting critical thermal limits (Das et al., 2004; Dalvi et al., 2009; Barrionuevo \& Fernandes, 1995; Currie et al., 1998; Prodocimo \& Freire, 2001), we focused on a single population of $P$. caucana. Because populations might be locally adapted or show long-term effects of diet and other environmental factors (Feminella \& Mattheus, 1984; Atwood et al., 2003; Narum et al., 2013), the conclusions that follow regarding vulnerability to climate change are preliminary and subject to revision once more populations of this species are assessed. The information is nonetheless the best available so far for P. caucana.

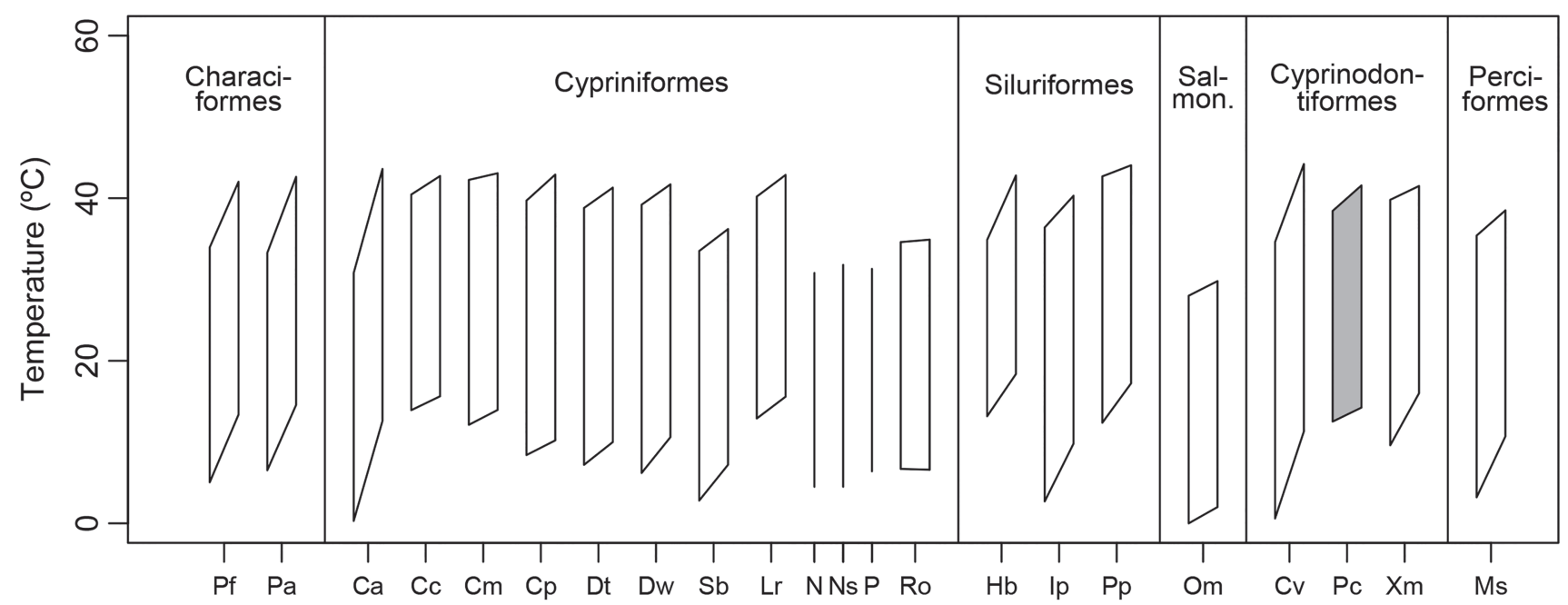

Fig. 2. Comparison of Critical Thermal (CT) limits for Poecilia caucana (Pc, grey polygon) and a sample of species with $\mathrm{CT}_{\min }$ and $\mathrm{CT}_{\max }$ data available in the literature. Polygons are formed by two vertical lines representing the CT tolerance ranges observed at the lowest and highest acclimation temperatures used in each study. The polygons have an arbitrary width that does not reflect the range of acclimation temperatures used among different studies. The top and bottom lines of each polygon join, respectively, the $\mathrm{CT}_{\max }$ and $\mathrm{CT}_{\min }$ values for each species. Three species (N, Ns, and $\mathrm{P}$ ) having data for only one acclimation temperature are represented by vertical lines. $\mathrm{Pf}=$ Prochilodus scrofa (currently Prochilodus lineatus), fry, and Ps = P. scrofa, adults (Barrionuevo \& Fernandes, 1995); Ca = Carassius auratus (Ford \& Beitinger, 2005); Cc = Catla catla and $\mathrm{Cm}=$ Cirrhinus mrigala (Das et al., 2004); $\mathrm{Cp}=$ Cyprinus carpio (Chatterjee et al., 2004); Danio rerio, transgenic breed, and D. rerio, wild (Cortemeglia \& Beitinger, 2005); $\mathrm{Sb}=$ Siphateles bicolor (McClanhan et al., 1986); Lr = Labeo rohita (Chatterjee et al., 2004; Das et al., 2004); $\mathrm{N}=$ Notropis chrysocephalus, Ns $=$ N. spilopterus, $\mathrm{P}=$ Pimephales notatus (Hockett \& Mundahl, 1989); Ro = Rhinichthys osculus (Kaya et al., 1992); Hb = Horabagrus_brachysoma (Dalvi et al., 2009); Ip = Ictalurus punctatus (Currie et al., 1998); Pp = Pangasius pangasius (Debnath et al., 2006); Om = Oncorhynchus mykiss (Currie et al., 1998); Cv = Cyprinodon variegatus (Bennett \& Beitinger, 1997); Pc = Poecilia caucana (this study); $\mathrm{Xm}=$ Xiphophorus maculatus (Prodocimo \& Freire, 2001); Ms = Micropterus salmoides (Currie et al., 1998). 


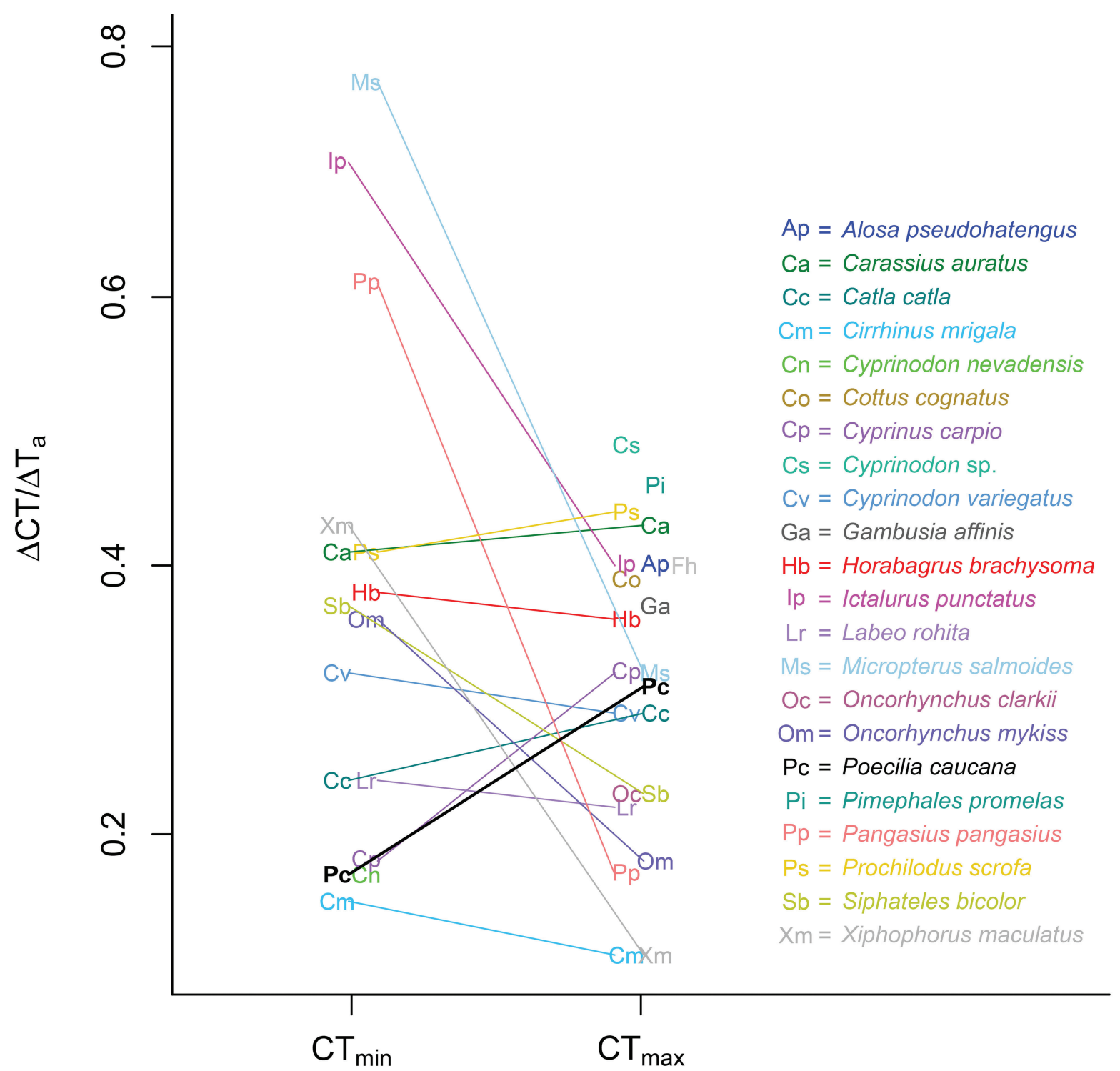

Fig. 3. Comparison of acclimation capacity for Poecilia caucana (Pc, bold letter and thicker line) and a sample of species with $\mathrm{CT}$ and acclimation temperature values available in the literature. Lines join acclimation capacities for $\mathrm{CT}_{\text {min }}$ and $\mathrm{CT}_{\max }$ of the same species, when both values are available. Symbols are jittered in the horizontal axis to avoid crowding. Abbreviations as in Fig. 2 except for Ap = Alosa pseudoharengus (Otto et al., 1976); $\mathrm{Cn}=$ Cyprinodon nevadensis (Feldmeth et al., 1974); Cs = Cyprinodon sp. (Otto \& Gerking, 1973); Fh = Fundulus heteroclitus (Bulger \& Tremaine, 1985); Ga = Gambusia affinis (Otto, 1973, 1974); Oc = Oncorhynchus clarkii (Heath, 1963).

Our literature survey revealed that most available data on thermal tolerance in fishes are biased to the temperate zone (and focus on the family Cyprinidae), an effect of greater research efforts in North America and Europe. Thermal tolerance data remain lacking for most freshwater fish species despite their extreme diversity (Lundberg et al., 2000) and despite how essential such data are for understanding the natural history and range limits of species, and hence their potential responses to environmental change. In the case of $P$. caucana, for example, the relatively low tolerance to cool temperatures we observed may explain why this species is restricted to warm elevations below $1500 \mathrm{~m}$ (Maldonado et al., 2006). Thermal tolerance data may also be useful to estimate the ability of species to tolerate changes in water temperature associated with global warming or with industrial discharges. It appears unlikely that the temperature changes projected even under the most pessimistic global warming scenarios (Walters et al., 2012) pose a risk for the viability of populations of $P$. caucana. On the other hand, streams can reach high temperatures due to wastewater from industrial plants $(c$. $50^{\circ} \mathrm{C}$ in some sites; Cairns, 1969), which may threaten its local persistence. More studies on the thermal biology of $P$. caucana and other tropical fish species are needed to be able to forecast effects and manage populations in the face of global change. 


\section{Acknowledgements}

Adolfo Amézquita at the Departamento de Ciencias Biológicas of the Universidad de los Andes provided equipment for experimentation. Juan Pablo Bueno, Laura Natalia Céspedes, Juliana Cuccaro, Juan Fernando De la Hoz, Ana Maria Galeano, Santiago Herrera, David Ocampo, Ángela Perilla and Simón Quintero helped throughout experimentation and fish maintenance. Jorge Mejía facilitated access to the field site in his property. Ángela Celis, Egna Mantilla, Julián Lozano, members of the Laboratorio de Biología Evolutiva de Vertebrados at Universidad de los Andes, and two anonymous reviewers made valuable comments on the manuscript.

\section{References}

Araújo, M. B., F. Ferri-Yáñez, F. Bozinovic, P. A. Marquet, F. Valladares \& S. L. Chown. 2013. Heat freezes niche evolution. Ecology Letters, 16: 1206-1219.

Atwood, H. L., J. R. Tomasso, K. Webb \& D. M. Gatlin III. 2003. Low-temperature tolerance of Nile tilapia, Oreochromis niloticus: effects of environmental and dietary factors. Aquaculture Research, 34: 241-251.

Barrionuevo, W. R. \& M. N. Fernandes. 1995. Critical thermal maxima and minima for curimbatá, Prochilodus scrofa Steindachner, of two different sizes. Aquaculture Research, 26: 447-450.

Beitinger, T. L., W. A. Bennett \& R. W. McCauley. 2000. Temperature tolerances of North American freshwater fishes exposed to dynamic changes in temperature. Environmental Biology of Fishes, 58: 237-275.

Bennett, A. F. 1990. Thermal dependence of locomotor capacity. American Journal of Physiology, 259: R253-R258.

Bierbach, D., E. Schleucher, P. Hildenbrand, A. Köhler, L. Arias-Rodriguez, R. Riesch \& M. Plath. 2010. Thermal tolerances in mollies (Poecilia spp.): reduced physiological flexibility in stable environments? Bulletin of Fish Biology, 12: 83-89.

Brett, J. R. 1971. Energetic responses of salmon to temperature. A study of some thermal relations in the physiology and freshwater ecology of sockeye salmon (Oncorhynchus nerka). American Zoologist, 11: 99-113.

Bulger, A. J. \& R. J. Schultz. 1982. Origin of thermal adaptations in northern versus southern populations of a unisexual hybrid fish. Evolution, 36: 1041-1050.

Bulger, A. J. \& S. C. Tremaine. 1985. Magnitude of seasonal effects on heat tolerance in Fundulus heteroclitus. Physiological Zoology, 58: 197-204.

Cairns Jr., J. 1969. The response of fresh-water protozoan communities to heated waste waters. Chesapeake Science, 10: 177-185.

Chatterjee, N., A. K. Pal, S. M. Manush, T. Das \& S. C. Mukherjee. 2004. Thermal tolerance and oxygen consumption of Labeo rohita and Cyprinus carpio early fingerlings acclimated to three different temperatures. Journal of Thermal Biology, 29: 265-270.

Cortemeglia, C. \& T. L. Beitinger. 2005. Temperature tolerances of wild-type and red transgenic zebra danios. Transactions of the American Fisheries Society, 134: 1431-1437.
Currie, R. J., W. A. Bennett \& T. L. Beitinger. 1998. Critical thermal minima and maxima of three freshwater gamefish species acclimated to constant temperatures. Environmental Biology of Fishes, 51: 187-200.

Dalvi, R. S., A. K. Pal, L. R. Tiwari, T. Das \& K. Baruah. 2009. Thermal tolerance and oxygen consumption rates of the catfish Horabagrus brachysoma (Günther) acclimated to different temperatures. Aquaculture, 295: 116-119.

Das, T., A. K. Pal, S. K. Chakraborty, S. M. Manush, N. Chatterjee \& S. C. Mukherjee. 2004. Thermal tolerance and oxygen consumption of Indian major carps acclimated to four temperatures. Journal of Thermal Biology, 29: 157163.

Debnath, D., A.K. Pal, N. P. Sahu, K. Baruah, S. Yengkokpam, T. Das \& S. M. Manush. 2006. Thermal tolerance and metabolic activity of yellowtail catfish Pangasius pangasius (Hamilton) advanced fingerlings with emphasis on their culture potential. Aquaculture, 258: 606-610.

Deutsch, C. A., J. J. Tewksbury, R. B. Huey, K. S. Sheldon, C. K. Ghalambor, D. C. Haak \& P. R. Martin. 2008. Impacts of climate warming on terrestrial ectotherms across latitude. Proceedings of the National Academy of Sciences, 105: 6668-6672.

Di Prisco, G. \& B. Giardina. 1996. Temperature adaptation: molecular aspects. Pp. 23-51. In: Johnston, I. A. \& A. F. Bennet (Eds.). Animals and temperature. Phenotypic and evolutionary adaptation. New York, Cambridge University Press.

Feldmeth, C. R., E. A. Stone \& J. H. Brown. 1974. An increased scope for thermal tolerance upon acclimating pupfish (Cyprinodon) to cycling temperatures. Journal of Comparative Physiology, 89: 39-44.

Feminella, J. W. \& W. J. Matthews. 1984. Intraspecific differences in thermal tolerance of Etheostoma spectabile (Agassiz) in constant versus fluctuating environments. Journal of Fish Biology, 25: 455-461.

Ford, T. \& T. L. Beitinger. 2005. Temperature tolerance in the goldfish, Carassius auratus. Journal of Thermal Biology, 30: 147-152.

Ghalambor, C. K., R. B. Huey, P. R. Martin, J. J. Tewksbury \& G. Wang. 2006. Are mountain passes higher in the tropics? Janzen's hypothesis revisited. Integrative and Comparative Biology, 46: 5-17.

Gracey, A. Y., J. Logue, P. E. Tiku \& A. R. Cossins. 1996. Adaptation of biological membranes to temperature: Biophysical perspectives and molecular mechanisms. Pp. 1-22. In: Johnston, I.A. \& A. F. Bennet (Eds.). Animals and temperature. Phenotypic and evolutionary adaptation. New York, Cambridge University Press.

Heath, W. G. 1963. Thermoperiodism in sea-run cutthroat trout (Salmo clarki clarki). Science, 142: 486-488.

Hernández, M., L. F. Bückle \& S. Espina. 2002. Temperature preference and acclimation in Poecilia sphenops (Pisces, Poeciliidae). Aquaculture Research, 33: 933-940.

Hockett, C. T. \& N. D. Mundahl. 1989. Effects of black spot disease on thermal tolerances and condition factors of three cyprinid fishes. Journal of Freshwater Ecology, 5: 67-72.

Janzen, D. H. 1967. Why mountain passes are higher in the tropics. American Naturalist, 101: 233-249.

Johansen, P. H. 1985. Female pheromone and the behaviour of male guppies (Poecilia reticulata) in a temperature gradient. Canadian Journal of Zoology, 63: 1211-1213. 
Johnston, I. A. \& A. F. Bennett. (Eds.). 1996. Animals and temperature: phenotypic and evolutionary adaptation. New York, Cambridge University Press, 419p.

Kuparinen, A., J. M. Cano, J. Loehr, G. Herczeg, A. Gonda \& J. Merilä. 2011. Fish age at maturation is influenced by temperature independently of growth. Oecologia, 167: 435443.

Lutterschmidt, W. I. \& V. H. Hutchison. 1997. The critical thermal maximum: history and critique. Canadian Journal of Zoology, 75: 1561-1574.

Maldonado-Ocampo, J. A., A. Ortega-Lara, J. S. U. Oviedo, G. G. Galvis, F. A. Villa-Navarro, L. V. Gamboa, S. PradaPedreros \& C. Ardila Rodríguez. 2005. Peces de los Andes de Colombia. Bogotá, Instituto de Investigación de Recursos Biológicos Alexander von Humboldt, 346p.

Maldonado-Ocampo, J. A., R. P. Vari \& J. S. Usma. 2008. Checklist of the freshwater fishes of Colombia. Biota Colombiana, 9: 143-237.

Manush, S. M., A. K. Pal, N. Chatterjee, T. Das \& S. C. Mukherjee. 2004. Thermal tolerance and oxygen consumption of Macrobrachium rosenbergii acclimated to three temperatures. Journal of Thermal Biology, 29: 15-19.

Marshall, K. E. \& B. J. Sinclair. 2011. The sub-lethal effects of repeated freezing in the woolly bear caterpillar Pyrrharctia isabella. The Journal of Experimental Biology, 214: 12051212.

Narum, S. R., N. R. Campbell, K. A. Meyer, M. R. Miller \& R. W. Hardy. 2013. Thermal adaptation and acclimation of ectotherms from differing aquatic climates. Molecular Ecology, 22: 3090-3097.

Ohlberger, J., T. Mehner, G. Staaks \& F. Hölker. 2012. Intraspecific temperature dependence of the scaling of metabolic rate with body mass in fishes and its ecological implications. Oikos, 12: 245-251.

Otto, R. G. \& S. D. Gerking. 1973. Heat tolerance of a Death Valley pupfish (genus Cyprinodon). Physiological Zoology, 46: 43-49.

Otto, R. G. 1973. Temperature tolerance of the mosquitofish, Gambusia affinis (Baird and Girard). Journal of Fish Biology, 5: 575-585.

Otto, R. G. 1974. The effects of acclimation to cyclic thermal regimes on heat tolerance of the western mosquitofish. Transactions of the American Fisheries Society, 103: 331335.

Otto, R. G., M. A. Kitchel \& J. O. H. Rice. 1976. Lethal and preferred temperatures of the alewife (Alosa pseudoharengus) in Lake Michigan. Transactions of the American Fisheries Society, 105: 96-106.

Persson, L. 1986. Temperature-induced shift in foraging ability in two fish species, roach (Rutilus rutilus) and perch (Perca fluviatilis): implications for coexistence between poikilotherms. Journal of Animal Ecology, 55: 829-839.
Pörtner, H. O. \& R. Knust. 2007. Climate change affects marine fishes through the oxygen limitation of thermal tolerance. Science, 315: 95-97.

Pörtner, H. O. \& A. P Farrell. 2008. Physiology and climate change. Science, 322: 690-692.

Prodocimo, V. \& C. A. Freire. 2001. Critical thermal maxima and minima of the platyfish Xiphophorus maculatus Günther (Poecillidae, Cyprinodontiformes) - a tropical species of ornamental freshwater fish. Revista Brasileira de Zoologia, 18: $97-106$.

R Core Team. 2015. R: A language and environment for statistical computing (Version 3.2.0). R Foundation for Statistical Computing, Vienna, Austria. Available from: http://www.Rproject.org/ (Date of access 10 January 2015).

Sala, O. E., F. S. Chapin, J. J. Armesto, E. Berlow, J. Bloomfield, R. Dirzo, E. Huber-Sanwald, L. F. Huenneke, R. B. Jackson, A. Kinzig, R. Leemans, D. M. Lodge, H. A. Mooney, M. Oesterheld, N. L. Poff, M. T. Sykes, B. H. Walker, M. Walker \& D. H. Wall. 2000. Global biodiversity scenarios for the year 2100. Science, 287: 1770-1774.

Sheldon, K. S., S. Yang \& J. J. Tewksbury. 2011. Climate change and community disassembly: impacts of warming on tropical and temperate montane community structure. Ecology Letters, 14: 1191-1200.

Sheldon, K. S. \& J. J. Tewksbury. 2014. The impact of seasonality in temperature on thermal tolerance and elevational range size. Ecology, 95: 2134-2143.

Somero, G. N. 2002. Thermal physiology and vertical zonation of intertidal animals: optima, limits, and costs of living. Integrative and Comparative Biology, 42: 780-789.

Stillman, J. H. 2003. Acclimation capacity underlies susceptibility to climate change. Science, 301: 65-65.

Terblanche, J. S., J. A. Deere, S. Clusella-Trullas, C. Janion \& S. L. Chown. 2007. Critical thermal limits depend on methodological context. Proceedings of the Royal Society B: Biological Sciences, 274: 2935-2943.

Verhoeven, K. J., K. L. Simonsen \& L. M. McIntyre. 2005. Implementing false discovery rate control: increasing your power. Oikos, 108: 643-647.

Walters, R. J., W. U. Blanckenhorn \& D. Berger. 2012. Forecasting extinction risk of ectotherms under climate warming: an evolutionary perspective. Functional Ecology, 26: $1324-1338$.
Submitted October 12, 2015

Accepted January 13, 2016 by Bernardo Baldisserotto 